\title{
Analisis Rasio Keuangan terhadap Harga Saham pada Perusahaan Food and Beverages
}

\author{
Namira Ufrida Rahmi ${ }^{1 *}$, Andrew ${ }^{2}$, Angelia Stefani ${ }^{3}$, Fenita $^{4}$ \\ 1,2,3,4) Universitas Prima Indonesia \\ namiraufridarahmi@unprimdn.ac.id, ajonatan988@gmail.com, angelsxchen@gmail.com, \\ fenita1303@gmail.com
}

*Penulis Korespondensi

$\begin{array}{ll}\text { Dikirim } & : \text { 27 Juni } 2021 \\ \text { Diterima } & : \text { 18 Juli 2021 } \\ \text { Dipublikasikan } & : \text { 1 Agustus 2021 }\end{array}$

\begin{abstract}
This research was conducted with the aim of examining the effect of Current Ratio, Quick Ratio, Net Profit Margin and Return on Equity on stock prices in food \& beverage sector companies listed on the Indonesia Stock Exchange from 2013 to 2019. The population is the Food \& Beverages sector companies listed on the IDX in 2013-2019. The sample was taken using purposive sampling method, so that the sample becomes 70 observation. This research was classified as quantitative research and the type of research is descriptive. The data analysis technique was carried out by using multiple linear regression test using the SPSS ver 25 analysis tool. The results showed that Current Ratio partially has a negative and insignificant effect on stock prices. Quick Ratio partially has a positive and insignificant effect on stock prices. Net Profit Margin partially has a positive and significant effect on stock price. And, Return on Equity partially has a negative and insignificant effect on stock prices. Meanwhile, simultaneously, Current Ratio, Quick Ratio, Net Profit Margin and Return on Equity have a positive and significant effect on stock prices in food and beverages sector companies listed on the Indonesia Stock Exchange in 2013-2019.
\end{abstract}

Keywords : Stock Prices; Current Ratio; Quick Ratio; Net Profit Margin; Return on Equity

\section{PENDAHULUAN}

Perkembangan dunia usaha dalam era globalisasi begitu pesat, hal tersebut terlihat dari kemunculan berbagai usaha baik yang menghasilkan sebuah barang ataupun jasa. Dalam memproduksi barang dan jasa, sangat erat kaitannya dengan penanaman modal baik investor dalam negeri ataupun luar negeri. Penanaman modal di Indonesia, terutama pada perusahaan terbuka tidak terlepas dari peran Bursa Efek Indonesia sebagai penyelenggara dan penyedia sistem sarana dalam pasar modal. Dalam pasar modal Indonesia, terdapat perusahaan dengan berbagai sektor. Sektor food and beverages menjadi sektor yang berpengaruh dalam pasar modal, dikarenakan sektor food and beverages merupakan sektor yang sangat penting dalam kehidupan masyarakat.

Perusahaan sektor food and beverages berkaitan dengan kebutuhan primer 
masyarakat tentu menarik minat investor untuk berinvestasi. Dengan meningkatnya minat investasi investor, tentu akan berdampak pada harga saham perusahaan tersebut. Faktor penentu kenaikan harga saham adalah demand dan supply saham tersebut. Semakin tinggi minat investor terhadap saham sebuah perusahaan, maka memunculkan permintaan yang tinggi terhadap saham emiten tersebut. Dengan demand yang tinggi, maka akan meningkatkan harga saham perusahaan tersebut. Harga saham sebuah perusahaan dapat menjadi salah satu penilai kinerja perusahaan. Dari data harga saham perusahaan food and beverages periode 2013 - 2019, harga saham perusahaan food and beverages mengalami fluktuasi dan mayoritas cenderung mengalami kenaikan.

Dalam melakukan investasi, investor akan memilih perusahaan yang memiliki performa dan kinerja yang baik. Performa perusahaan dapat terlihat dari pelaporan keuangan setiap tahunnya. Kinerja perusahaan dapat dinilai dengan beberapa indikator. Salah satu indikator dalam penilaian kinerja keuangan yaitu dengan menggunakan rasio likuiditas. Rasio lancar merupakan salah satu faktor yang cukup penting dalam analisis kinerja keuangan perusahaan. Kinerja perusahaan yang baik akan menambah minat investor terhadap perusahaan tersebut. Dengan bertambahnya minat investor, juga akan berdampak positif pada harga saham perusahaan tersebut. Penelitian terdahulu yang dilakukan oleh (Kundiman \& Hakim, 2017) menunjukkan bahwa Current Ratio berpengaruh positif terhadap harga saham. Penelitian oleh (Nahariyah, 2017) juga menunjukkan Current Ratio berpengaruh signifikan terhadap harga saham. Sedangkan, menurut penelitian yang dilakukan (Tewal \& Jan, 2017) menunjukkan bahwa Current Ratio berpengaruh negatif dan tidak signifikan terhadap harga saham. Penelitian oleh (Sukayasih et al., 2019) menunjukkan bahwa Current Ratio berpengaruh negatif terhadap harga saham.

Rasio likuiditas lain dalam penelitian ini yaitu rasio cepat. Rasio cepat dapat menjadi ukuran yang digunakan untuk mengetahui kemampuan perusahaan memenuhi kewajiban jangka pendek jika semua aset likuid dijual. Pemenuhan kewajiban perusahaan yang baik akan menjadi salah satu pertimbangan investor dalam berinvestasi. Dengan semakin banyaknya investor yang berinvestasi di saham perusahaan tersebut, akan berdampak pada harga saham perusahaan tersebut. Penelitian sebelumnya yang dilakukan oleh (Sari, 2020) menunjukkan bahwa Quick Ratio berpengaruh positif terhadap harga saham. Penelitian oleh (Sari, 2018) juga menunjukkan bahwa Quick Ratio berpengaruh positif terhadap harga saham. Sedangkan, hasil penelitian oleh (Ramdayanti et al., 2019) menunjukkan bahwa Quick Ratio tidak berpengaruh terhadap harga saham. Penelitian oleh (Suryanengsih \& Kharisma, 2020) juga menunjukkan bahwa Quick Ratio tidak berpengaruh terhadap harga saham.

Selain rasio likuiditas, kinerja keuangan sebuah perusahaan dapat dianalisis dengan rasio profitabilitas. Adapun beberapa rasio profitabilitas yang digunakan dalam penelitian ini yaitu Net Profit Margin dan Return on Equity. Net Profit Margin dapat dijadikan salah satu jenis rasio yang esensial dalam analisis rasio keuangan perusahaan karena rasio ini berhubungan dengan kinerja perusahaan. Dengan kemampuan perusahaan yang tinggi dalam memperoleh laba akan menambah ketertarikan investor terhadap perusahaan tersebut dan tentunya akan berdampak positif pada harga saham perusahaan tersebut. Menurut penelitian yang dilakukan oleh (Amalya, 2018) menunjukkan bahwa Net Profit Margin berpengaruh positif terhadap harga saham. Penelitian oleh (Mangeta et al., 2019) juga menunjukkan bahwa Net Profit Margin berpengaruh signifikan terhadap harga saham. Sedangkan, hasil 
penelitian oleh (Ambarwati et al., 2019) menunjukkan bahwa Net Profit Margin berpengaruh negatif terhadap harga saham. Hasil penelitian serupa oleh (Tewal \& Jan, 2017) menunjukkan bahwa Net Profit Margin berpengaruh negatif dan signifikan terhadap harga saham.

Return on Equity juga merupakan salah satu rasio profitabilitas yang dibahas dalam penelitian ini. Rasio ini digunakan untuk mengetahui efisiensi penggunaan modal yang diinvestasikan pemegang saham dalam menghasilkan laba sehingga digunakan sebagai indikator utama oleh investor dalam pengambilan keputusan investasi. Umumnya dalam berinvestasi, investor akan memilih perusahaan dengan kemampuan dan efektivitas dalam penggunaan modal yang baik. Semakin tinggi minat investor terhadap suatu perusahaan akan berdampak positif pada harga saham perusahaan tersebut. Penelitian yang dilakukan oleh (Afiah Aprilia Abbas, 2019) menunjukkan bahwa Return on Equity berpengaruh positif terhadap harga saham. Hasil penelitian oleh (Ramdayanti et al., 2019) juga menunjukkan Return on Equity berpengaruh positif dan signifikan terhadap harga saham. Di sisi lain, penelitian yang dilakukan oleh (Alipudin, 2016) menunjukkan bahwa Return on Equity berpengaruh negatif terhadap harga saham. Penelitian oleh (Kundiman \& Hakim, 2017) juga menunjukkan bahwa Return on Equity tidak berpengaruh signifikan terhadap harga saham.

Berdasarkan beberapa penelitian terdahulu yang peneliti amati, terdapat perbedaan hasil perbedaan (research gap). Perbedaan hasil penelitian ini juga didukung oleh data laporan keuangan yang peneliti amati. Dari data laporan keuangan beberapa perusahaan yang peneliti amati pada tahun 2013-2019, aktiva lancar pada perusahaan sektor Food \& Beverage yang terdaftar di Bursa Efek Indonesia mengalami kenaikan namun tidak diikuti dengan kenaikan harga saham, penurunan hutang lancar tidak selalu diikuti dengan kenaikan harga saham, kenaikan penjualan bersih tidak selalu diikuti dengan kenaikan harga saham, dan penurunan laba bersih juga tidak selalu diikuti dengan penurunan harga saham. Perbedaan hasil penelitian yang peneliti amati dan didukung oleh data laporan keuangan, peneliti merasa tertarik untuk melakukan penelitian kembali pengaruh Current Ratio, Quick Ratio, Net Profit Margin dan Return on Equity pada harga saham di perusahaan sektor food and beverages yang tercatat di Bursa Efek Indonesia tahun 2013 - 2019.

\section{Pengaruh Current Ratio Terhadap Harga Saham.}

\section{STUDI LITERATUR}

Menurut_(Fahmi, 2017), Current Ratio dengan ukuran yang banyak dipergunakan perusahaan dalam memenuhi kewajiban yang berjangka pendek. Aktiva lancar yang tinggi menunjukkan kinerja perusahaan yang baik, dikarenakan perusahaan dinilai mampu melunasi kewajiban yang akan jatuh tempo sesuai waktunya. Perusahaan yang mampu melunasi kewajibannya akan menarik minat investor, karena perusahaan berkinerja sehat dan dinilai mampu beroperasi untuk jangka yang panjang, sehingga layak untuk diinvestasikan. Dengan meningkatnya minat investor terhadap sebuah perusahaan, akan meningkatkan harga saham perusahaan tersebut. Penelitian yang dilakukan (Kundiman \& Hakim, 2017) menunjukkan bahwa Current Ratio berpengaruh terhadap harga saham. Hasil penelitian (Fitrianingsih \& Budiansyah, 2019) juga menunjukkan bahwa Current Ratio berpengaruh positif terhadap harga saham.

$\mathrm{H}_{1}$ : Current Ratio berpengaruh terhadap harga saham pada perusahaan sektor Food and 
Owner: Riset \& Jurnal Akuntansi

e-ISSN : 2548-9224 |p-ISSN : 2548-7507

Volume 5 Nomor 5, Agustus 2021

DOI : https://doi.org/10.33395/owner.v5i2.481

beverages yang terdaftar di Bursa Efek Indonesia tahun 2013 - 2019

Pengaruh Quick Ratio Terhadap Harga Saham.

Menurut __(Kasmir, 2018) Quick Ratio merupakan rasio yang sanggup menggambarkan mengenai kapasitas perusahaan dalam membayar tanggung jawab yang berjangka pendek. Aktiva lancar perusahaan yang memadai menggambarkan kinerja perusahaan yang baik. Perusahaan dinilai sehat, karena perusahaan mampu menjaga operasional perusahaan dan melunasi kewajiban tepat waktu. Perusahaan yang sehat akan dijadikan salah satu pilihan investor dalam berinvestasi. Dengan naiknya minat investor dalam berinvestasi, tentu akan meningkatkan harga saham perusahaan tersebut. Penelitian yang dilakukan oleh (Sari, 2020) menunjukkan Quick Ratio berpengaruh positif pada harga saham.

$\mathrm{H}_{2}$ : Quick Ratio berpengaruh terhadap harga saham pada perusahaan sektor Food and beverages yang terdaftar di Bursa Efek Indonesia tahun 2013 - 2019

\section{Pengaruh Net Profit Margin Terhadap Harga Saham}

Menurut (Kasmir, 2018), jika margin laba bersih adalah rasio keuangan yang bermMaksud mengukur laba dengan memperbandingkan keuntungan setelah bunga dan pajak dengan hasil penjualan. Perusahaan yang memiliki laba positif menunjukkan perusahaan tersebut produktif. Perusahaan yang produktif tentu tak luput dari perhatian investor. Investor yang tertarik dengan perusahaan dengan laba bersih yang tinggi akan berinvestasi pada perusahaan tersebut dan tentunya berdampak baik pada saham perusahaan tersebut. Penelitian yang dilakukan oleh (Ambarwati et al., 2019) menunjukkan bahwa Net Profit Margin berpengaruh negatif terhadap harga saham.

$\mathrm{H}_{3}$ : Net Profit Margin berpengaruh terhadap harga saham pada perusahaan sektor Food and beverages yang terdaftar di Bursa Efek Indonesia tahun 2013 - 2019

\section{Pengaruh Return on Equity (ROE) Terhadap Harga Saham.}

Pendapat dari (Alipudin, 2016) ROE untuk menganalisis seberapa jauh perusahaan memanfaatkan sumber daya yang tersedia untuk sanggup memberi keuntungan atas ekuitas. Keefektifan perusahaan dalam pemanfaatan ekuitas untuk menghasilkan laba akan menarik minat investor. Investor akan menilai perusahaan tersebut berhasil dalam pemanfaatan ekuitas perusahaan itu, sehingga layak untuk diinvestasikan. Semakin tertarik investor, maka akan berdampak pada harga saham perusahaan itu. Penelitian yang dilakukan oleh (Alfiah \& Diyani, 2018) menunjukkan bahwa Return on Equity tidak berpengaruh signifikan terhadap harga saham.

$\mathrm{H}_{4}$ : Return on Equity berpengaruh terhadap harga saham pada perusahaan sektor Food and beverages yang terdaftar di Bursa Efek Indonesia tahun 2013 - 2019

\section{Kerangka Konseptual}




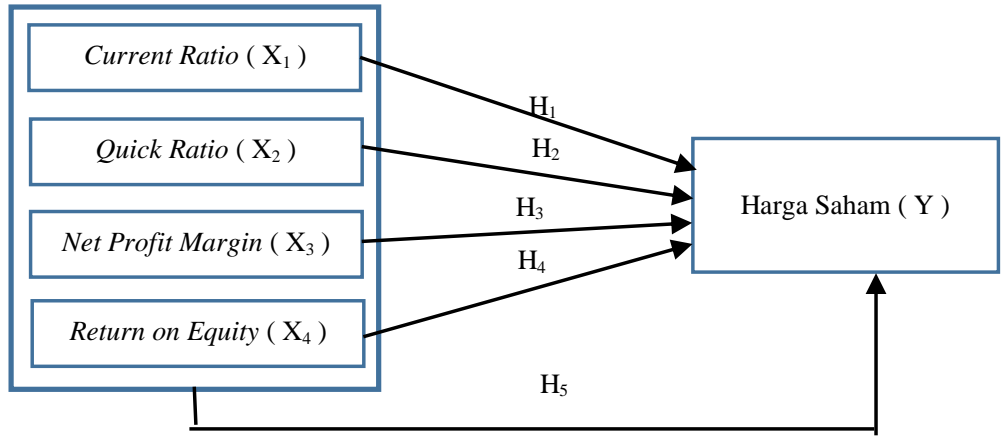

Gambar 1. Kerangka Konseptual

\section{Metode Penelitian}

\section{METODE}

Penelitian ini didasarkan pada pendekatan kuantitatif. Penelitian ini menggunakan data sekunder dan data berjenis data kuantitatif. Teknik pengumpulan data pada penelitian ini dengan teknik dokumentasi pada laporan keuangan perusahaan yang tersedia di website www.idx.co.id. Pengolahan data dilakukan dengan statistik deskriptif. Populasi penelitian ini adalah perusahaan sektor food and beverages yang tercatat di BEI dengan jumlah 26 perusahaan. Purposive sampling digunakan pada penelitian ini untuk penentuan sampel. Kriteria penentuan sampel adalah sebagai berikut:

1. Perusahaan sektor food and beverages yang tercatat di BEI dari tahun 2013-2019

2. Perusahaan sektor food and beverages yang rutin mempublikasikan laporan keuangan dari tahun 2013-2019.

3. Perusahaan sektor food and beverages yang memperoleh laba positif dari tahun 20132019

Tabel 1. Kriteria Penentuan Sampel Penelitian

\begin{tabular}{|c|l|c|}
\hline No & \multicolumn{1}{|c|}{ Kriteria } & $\begin{array}{c}\text { Jumlah } \\
\text { Sampel }\end{array}$ \\
\hline 1 & Perusahaan sektor food and beverages yang tercatat di BEI tahun 2013-2019 & 26 \\
\hline 2 & $\begin{array}{l}\text { Perusahaan sektor food and beverages yang tidak rutin mengeluarkan laporan } \\
\text { keuangan dari tahun 2013-2019 }\end{array}$ & -13 \\
\hline 3 & $\begin{array}{l}\text { Perusahaan sektor food and beverages yang tidak mendapatkan keuntungan } \\
\text { positif dari tahun 2013-2019 }\end{array}$ & -3 \\
\hline & Jumlah Perusahaan & 10 \\
\hline & \multicolumn{1}{|c|}{ Jumlah Sampel ( 10 perusahaan x 7 tahun ) } & 70 \\
\hline
\end{tabular}

Sumber : $\underline{\text { www.idx.co.id }}$

\section{Identifikasi Operasional Variabel} Variabel Independen

\section{Current Ratio}

Current Ratio ialah rasio untuk mengkalkulasi kemampuan aset likuid perusahaan membayar kewajiban yang berjangka pendek. Rumus Current Ratio menurut _(Kasmir, 2018) adalah sebagai berikut: 


$$
\text { (1). Current Ratio }=\frac{\text { Aktiva Lancar }}{\text { Hutang Lancar }}
$$

\section{Quick Ratio}

Quick Ratio ialah rasio untuk mengukur kapabilitas perusahaan dalam memenuhi hutang lancar menggunakan aset sangat likuid, diluar persediaan barang dagang. Rumus Quick Ratio menurut_(Kasmir, 2018) adalah sebagai berikut:

$$
\text { (2). Quick Ratio }=\frac{\text { Aktiva Lancar }- \text { Persediaan }}{\text { Hutang Lancar }}
$$

\section{Net Profit Margin}

Net Profit Margin ialah rasio yang berguna dalam menilai seberapa besar persentase keuntungan bersih sesudah dikurangi pajak pada penjualan bersih. Rumu s Net Profit Margin menurut_(Kasmir, 2018) adalah sebagai berikut:

$$
\text { (3). Net Profit Margin }=\frac{\text { Laba Bersih Setelah Pajak }}{\text { Penjualan }}
$$

\section{Return on Equity (ROE)}

Return on Equity adalah rasio yang mengukur seberapa efektif kemampuan ekuitas dalam memperoleh laba bersih. Rumus Return on Equity menurut_(Kasmir, 2018) adalah sebagai berikut:

$$
\text { (4). Return on Equity }(\text { ROE })=\frac{\text { Laba Bersih }}{\text { Ekuitas }}
$$

\section{Variabel Dependen Harga Saham}

Harga saham adalah nilai nominal yang tercantum pada surat kepemilikan modal pada sebuah emiten didasarkan pada pasar dan diperngaruhi oleh permintaan serta penawaran dalam pasar modal.

$$
\text { (5). Harga Saham = Harga Saham Penutupan }
$$

\section{Uji Asumsi Klasik}

\section{Uji Normalitas}

Kriteria data dikatakan berdistribusi normal yakni jika datanya menyebar mendekati garis diagonalnya dan menyerupai bentuk lonceng pada histogram dan nilai sig. > 0,05.

\section{Uji Multikolinearitas}

Penentuan dengan melihat nilai VIF $<10$ atau nilai tolerance $>010$ maka tidak mengalami multikolinearitas.

\section{Uji Autokorelasi}

Tujuan dilakukannya pengujian ini yaitu untuk mengetahui apakah dalam model regresinya ada hubungan antar residual dalam periode $t$ dengan kesalahan dalam periode $t-1$ (sebelumnya). 


\section{Uji Heteroskedastisitas}

Berfungsi untuk melihat apakah model regresinya mempunyai perbedaan variasi dari variabel penggangu pengamatan ke pengamatan lainnya dan dilaksanakan dengan analisa grafik scatterplot.

\section{Model Analisis Data Penelitian}

Metode analisa data yang dipakai ini ialah uji linear berganda. Model regresi yang akan digunakan yaitu :

$$
\mathrm{Y}=\mathrm{a}+\mathrm{X}_{1} \mathrm{~b}_{1}+\mathrm{X}_{2} \mathrm{~b}_{2}+\mathrm{X}_{3} \mathrm{~b}_{3}+\mathrm{X}_{4} \mathrm{~b}_{4}+\mathrm{e}
$$

Keterangan

Y : Harga Saham

$\mathrm{X}_{1}:$ Current Ratio

$\mathrm{X}_{2}$ : Quick Ratio

$\mathrm{X}_{3}:$ Net Profit Margin

$\mathrm{X}_{4}$ : Return on Equity $\mathrm{b}_{1}$ : Koefisien Regresi Current Ratio

$\mathrm{b}_{2}$ : Koefisien Regresi Quick Ratio

$\mathrm{b}_{3}$ : Koefisien Regresi Net Profit Margin

$\mathrm{b}_{4}$ : Koefisien Regresi Return on Equity

e : error (tingkat kesalahan) 5\%

\section{Koefisien Determinasi Hipotesis}

Penentuan keputusan dengan melihat nilai koefisien determinasi $\left(\mathrm{R}^{2}\right)$ mendekati 1 , berarti kemampuan variabel bebas $(\mathrm{X})$ kuat pada variabel terikat $(\mathrm{Y})$ ataupun kebalikannya.

\section{Pengujian Hipotesis Secara Simultan (Uji F)}

Dasar pengambilan keputusan yakni jika $F_{\text {hitung }}>F_{\text {tabel }}$ berarti variabel independen secara simultan berpengaruh terhadap variabel dependen dan sebaliknya.

\section{Pengujian Hipotesis Secara Parsial (Uji t)}

Ketentuan dalam pengujian hipotesis yakni apabila nilai thitung $>t_{\text {tabel }}$ maka variabel independen secara parsial berpengaruh terhadap variabel dependen dan sebaliknya.

\section{Hasil Penelitian}

\section{HASIL}

Data diolah dengan menggunakan SPSS versi 25 dengan tahap berikut ini:

\section{Statistik Deskriptif}

Data penelitian ini dapat di rincikan :

Tabel 2. Statistik Deskriptif

\begin{tabular}{|l|c|r|r|r|r|}
\hline \multicolumn{7}{|c|}{ Descriptive Statistics } \\
\hline & $\mathrm{N}$ & Minimum & Maksimum & Mean & $\begin{array}{c}\text { Std. } \\
\text { Deviation }\end{array}$ \\
\hline CR & 70 & .51 & 5.11 & 2.0313 & 1.07513 \\
\hline QR & 70 & .09 & 3.62 & 1.4571 & .85942 \\
\hline
\end{tabular}




\begin{tabular}{|l|r|r|r|r|r|} 
NPM & 70 & .00 & .89 & .1041 & .12599 \\
\hline ROE & 70 & .00 & 1.68 & .2661 & .35261 \\
\hline HargaSaham & 70 & 180.00 & 30500.00 & 5302.1714 & 6213.84121 \\
\hline $\begin{array}{l}\text { Valid N } \\
\text { (listwise) }\end{array}$ & 70 & & & & \\
\hline
\end{tabular}

Sumber : Data Diolah (2020)

1. Current Ratio dengan jumlah sampel 70 dengan perincian nilai minimum 0,51 , nilai maksimum 5,11, mean 2,0313 dan standard deviasi 1,07513 .

2. Quick Ratio dengan sampel 70 dengan perincian nilai minimum 0,09 , nilai maksimum 3,62, mean 1,4571 dan standard deviasi 0,85942.

3. Net Profit Margin dengan sampel 70 dengan perincian nilai minimum 0,00 , nilai maksimum 0,89, mean 0,1041 dan standard deviasi 0,12599.

4. Return on Equity (ROE) dengan sampel 70 dengan perincian nilai minimum 0,00, nilai maksimum 1,68, mean 0,2661 dan standard deviasi 0,35261.

5. Harga saham dengan sampel 70 dengan perincian nilai minimum 180,00 , nilai maksimum $30.500,00$, mean 5.302,1714 dan standard deviasi 6.213,84121.

\section{Uji Asumsi Klasik}

Untuk mendapatkan hasil BLUE (Best Linear Unbiased Estimator), maka data harus melewati uji asumsi klasik. Peneliti melakukan transformasi data dikarenakan data tidak lulus uji asumsi klasik. Data tidak lolos uji normalitas, uji multikolinearitas, dan uji heteroskedastisitas. Transformasi dilakukan dengan melakukan Ln pada setiap variabel independen dan dependen. Dan mengakibatkan berkurangnya 1 data yang semula berjumlah 70 data menjadi 69 data.

\section{Uji Normalitas}

Salah satu syarat uji normalitas yaitu dengan Kolmogorov Smirnov Test. Jika nilai signifikan > 0,05, data berdistribusi normal dan disajikan dalam tabel dibawah ini.

Tabel 3. One-Sample Kolmogorov-Smirnov Test Sesudah Transformasi

\begin{tabular}{|c|c|c|}
\hline \multicolumn{3}{|c|}{ One-Sample Kolmogorov-Smirnov Test } \\
\hline & & Unstandardized Residual \\
\hline \multicolumn{2}{|l|}{$\mathrm{N}$} & 69 \\
\hline \multirow[t]{2}{*}{ Normal Parameters ${ }^{\mathrm{a}, \mathrm{b}}$} & Mean & .0000000 \\
\hline & Std. Deviation & .90912229 \\
\hline \multirow[t]{3}{*}{ Most Extreme Differences } & Absolute & .083 \\
\hline & Positive & .083 \\
\hline & Negative & -.067 \\
\hline \multicolumn{2}{|l|}{ Test Statistic } & .083 \\
\hline Asymp. Sig. (2-tailed) & & $.200^{\mathrm{c}, \mathrm{d}}$ \\
\hline \multicolumn{3}{|l|}{ a. Test distribution is Normal. } \\
\hline \multicolumn{3}{|c|}{ b. Calculated from data. } \\
\hline \multicolumn{3}{|c|}{ c. Lilliefors Significance Correction. } \\
\hline \multicolumn{3}{|c|}{ d. This is a lower bound of the true significance. } \\
\hline
\end{tabular}

Sumber : Data Diolah (2020) 
Pada tabel 3. One-Sample Kolmogorov-Smirnov Test Sesudah Transformasi, uji normalitas ini mempunyai nilai signifikan $0,200>0,05$, maka syarat data berdistribusi normal sudah terpenuhi. Analisis histogram dan normal P-Plot juga digunakan dalam penelitian ini. Berikut gambaran kedua grafik tersebut :

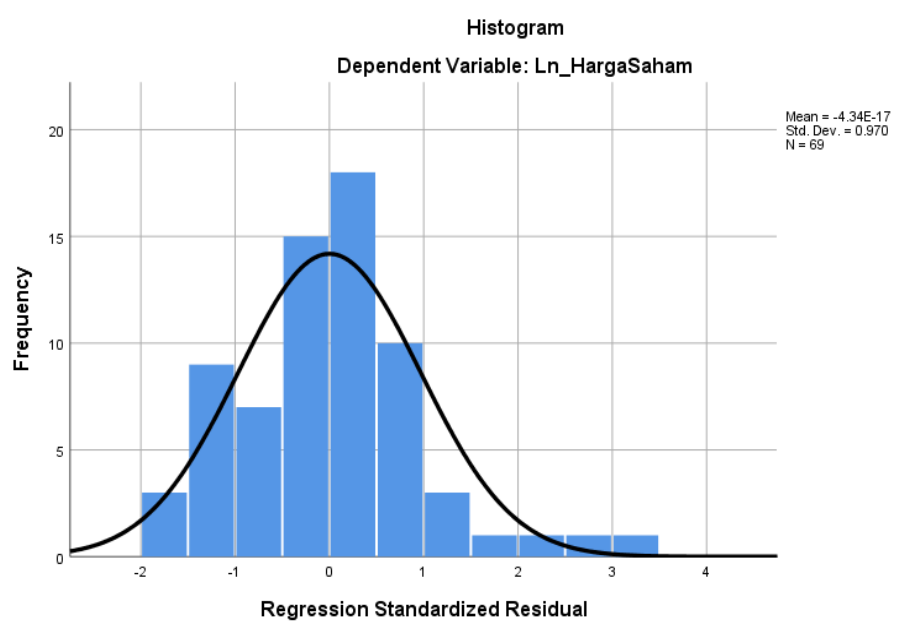

Gambar 2. Histogram Sesudah Transformasi

Sumber : Data Diolah (2020)

Dari gambar tersebut, memperlihatkan jika datanya berdistribusi dengan normal dikarenakan arah histogramnya tidak miring ke kiri dan menyerupai sebuah lonceng terbalik.

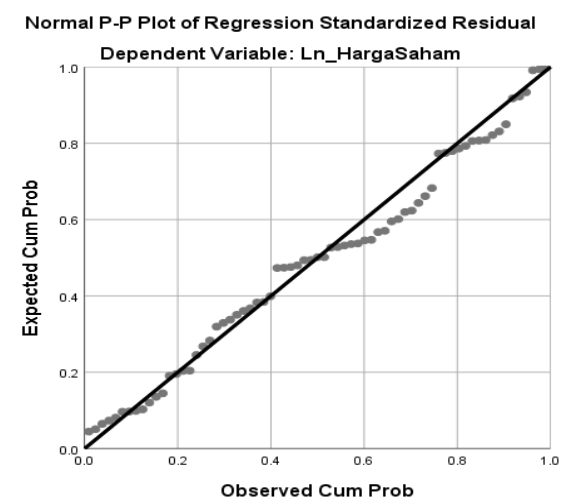

Gambar 3. Uji Normal Probability Plot Sesudah Transformasi

Sumber : Data Diolah (2020)

Dari hasil diatas, data dikatakan tersebar secara normal karena titiknya mendekati garis diagonal.

\section{Uji Multikolinearitas}

Penentuan keputusan adalah apabila nilai $V I F<10$ dan nilai tolerance $>0,10$, dikatakan regresi bebas multikolinearitas. Hasil pengujian ditampilkan di bawah ini : 
Tabel 4. Uji Multikolinearitas Sesudah Transformasi

\begin{tabular}{|c|c|c|c|}
\hline \multicolumn{4}{|c|}{ Coefficients $^{\mathrm{a}}$} \\
\hline \multirow{2}{*}{\multicolumn{2}{|c|}{ Model }} & \multicolumn{2}{|c|}{ Collinearity Statistics } \\
\hline & & Tolerance & VIF \\
\hline \multirow[t]{5}{*}{1} & (Constant) & & \\
\hline & Ln_CR & .244 & 4.093 \\
\hline & Ln_QR & .276 & 3.625 \\
\hline & Ln_NPM & .235 & 4.256 \\
\hline & Ln_ROE & .214 & 4.673 \\
\hline
\end{tabular}

Sumber : Data Diolah (2020)

Dari tabel tersebut nilai tolerance variabel $>0,1$ dan nilai VIF $<10$ memenuhi syarat untuk CR, QR, NPM, dan ROE disimpulkan tidak terjadi multikolinearitas.

\section{Uji Autokorelasi}

Dasar untuk menetapkan ada tidaknya gejala autokorelasi menggunakan uji DW. Hasil pengujiannya yakni :

Tabel 5. Uji Autokorelasi Sesudah Transformasi

\begin{tabular}{|l|c|r|r|r|r|}
\hline \multicolumn{7}{|c|}{ Model Summary $^{\mathbf{b}}$} \\
\hline Model & $\mathrm{R}$ & R Square & Adjusted R Square & Std. Error of the Estimate & Durbin-Watson \\
\hline 1 & $.661^{\mathrm{a}}$ & .437 & .401 & .93710 & 2.081 \\
\hline \multicolumn{2}{|l}{ a. Predictors: (Constant), Ln_ROE, Ln_QR, Ln_CR, Ln_NPM } \\
\hline
\end{tabular}

Sumber : Data Diolah (2020)

Berdasarkan pada tabel tersebut, nilai dw yakni 2,081. Hasil pengukurannya adalah jumlah sampel sebanyak $69, \mathrm{du}=1,7343.1,7343<2,081<4-1,7343$ atau $1,7343<2,081<2,2657$, sehingga ditarik kesimpulan data tidak mengalami gejala autokorelasi.

\section{Uji Heteroskedastisitas}

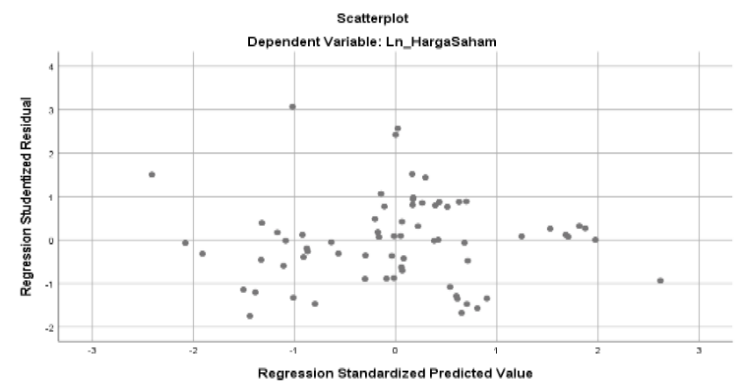

Gambar 4. Uji Heteroskedastisitas Sesudah Transformasi

Sumber : Data Diolah (2020) 
Owner: Riset \& Jurnal Akuntansi

e-ISSN : 2548-9224 |p-ISSN : 2548-7507

Volume 5 Nomor 5, Agustus 2021

DOI : https://doi.org/10.33395/owner.v5i2.481

Setelah dilakukan transformasi, data tersebut menyebar dengan acak dan disimpulkan data tersebut tidak mengalami gejala heteroskedastisitas.

Tabel 6. Uji Glejser Sesudah Transformasi

\begin{tabular}{|c|c|c|c|c|c|c|}
\hline \multicolumn{7}{|c|}{ Coefficients $^{\mathbf{a}}$} \\
\hline \multirow{2}{*}{\multicolumn{2}{|c|}{ Model }} & \multicolumn{2}{|c|}{ Unstandardized Coefficients } & \multirow{2}{*}{$\frac{\text { Standardized Coefficients }}{\text { Beta }}$} & \multirow[b]{2}{*}{$\mathrm{t}$} & \multirow[b]{2}{*}{ Sig. } \\
\hline & & $\mathrm{B}$ & Std. Error & & & \\
\hline \multirow[t]{5}{*}{1} & (Constant) & .394 & .274 & & 1.437 & .156 \\
\hline & Ln_CR & -.209 & .281 & -.179 & -.743 & .460 \\
\hline & Ln_QR & .397 & .213 & .423 & 1.864 & .067 \\
\hline & Ln_NPM & -.139 & .169 & -.203 & -.827 & .411 \\
\hline & Ln_ROE & .024 & .177 & .035 & .138 & .891 \\
\hline
\end{tabular}

Sumber : Data Diolah (2020)

Tabel di atas menunjukkan nilai signifikansi semua variabel $>0,05$ dan disimpulkan tidak mengalami heteroskedastisitas.

\section{Hasil Analisis Data}

\section{Analisis Regresi Linear Berganda}

Dalam melakukan analisis regresi linear berganda guna menyatakan nilai konstanta, nilai variable independen di tampilkan di bawah ini :

Tabel 7. Hasil Analisis Regresi Linier Berganda

\begin{tabular}{|c|c|c|c|c|c|c|}
\hline \multicolumn{7}{|c|}{ Coefficients $^{\mathrm{a}}$} \\
\hline \multirow{2}{*}{\multicolumn{2}{|c|}{ Model }} & \multicolumn{2}{|c|}{ Unstandardized Coefficients } & \multirow{2}{*}{$\frac{\text { Standardized Coefficients }}{\text { Beta }}$} & \multirow[b]{2}{*}{$\mathrm{t}$} & \multirow[b]{2}{*}{ Sig. } \\
\hline & & $\mathrm{B}$ & Std. Error & & & \\
\hline \multirow[t]{5}{*}{1} & (Constant) & 10.587 & .436 & & 24.282 & .000 \\
\hline & Ln_CR & -.578 & .447 & -.246 & -1.294 & .200 \\
\hline & Ln_QR & .344 & .339 & .182 & 1.016 & .313 \\
\hline & Ln_NPM & 1.058 & .268 & .763 & 3.941 & .000 \\
\hline & Ln_ROE & -.236 & .282 & -.170 & -.837 & .406 \\
\hline
\end{tabular}

a. Dependent Variable: Ln_HargaSaham

Sumber : Data Diolah (2020)

Ln_Harga Saham $=10,587-0,578$ Ln_CR + 0,344 Ln_QR + 1,058 Ln_NPM - 0,236 Ln_ROE

1. Nilai konstanta sebesar 10,587 satuan yang berarti jika Current Ratio, Quick Ratio, Net Profit Margin, Return on Equity bernilai nol maka harga saham sebesar 10,587 satuan.

2. Koefisien Current Ratio bernilai -0,578 satuan artinya variabel independen lainnya nol dan Current Ratio bernilai negatif berarti terjadi kenaikan Current Ratio tiap satuan menurunkan harga saham sebesar 0,578. 
3. Koefisien Quick Ratio bernilai 0,344 satuan artinya jika variabel independen lainnya nol dan Quick Ratio bernilai positif menunjukkan terjadi kenaikan Quick Ratio tiap satuan meningkatkan harga saham sebesar 0,344.

4. Koefisien Net Profit Margin bernilai 1,058 satuan artinya jika variabel independen lainnya nol dan Net Profit Margin bernilai positif menunjukkan terjadi kenaikan Net Profit Margin tiap satuan dapat meningkatkan harga saham sebesar 1,058.

5. Koefisien Return on Equity bernilai -0,236 satuan artinya jika variabel independen lainnya nol dan Return on Equity bernilai negatif menunjukkan terjadi kenaikan Return on Equity tiap satuan dapat menurunkan harga saham sebesar 0,236.

\section{Koefisien Determinasi $\left(\mathbf{R}^{2}\right)$}

Berfungsi untuk mengetahui kemampuan variabel independennya bisa menjelaskan variabel terikat. Berikut ini hasil dari pengujiannya :

Tabel 8. Koefisien Determinasi

\begin{tabular}{|l|c|r|r|r|}
\hline \multicolumn{5}{|c|}{ Model Summary $^{\mathbf{b}}$} \\
\hline Model & $\mathrm{R}$ & R Square & Adjusted R Square & Std. Error of the Estimate \\
\hline 1 & $.661^{\mathrm{a}}$ & .437 & .401 & .93710 \\
\hline a. Predictors: (Constant), Ln_ROE, Ln_QR, Ln_CR, Ln_NPM \\
\hline \multicolumn{4}{|l}{ b. Dependent Variable: Ln_HargaSaham } \\
\hline
\end{tabular}

Sumber : Data Diolah (2020)

Hasil pengujian menunjukkan adjusted $R$ Square $\left(\mathrm{R}^{2}\right)$ bernilai 0,401 atau $40,1 \%$ mempengaruhi harga saham dan selebihnya yakni 59,9\% di karenakan pengaruh dari variabel independen lainnya.

\section{Pengujian Hipotesis Secara Simultan (Uji Statistik F)}

Berfungsi untuk menguji apakah variabel independennya secara serentak mempengaruhi variabel dependennya.

Tabel 9. Hasil Uji Statistik F

\begin{tabular}{|c|c|c|c|c|c|c|}
\hline \multicolumn{7}{|c|}{ ANOVA $^{\mathrm{a}}$} \\
\hline \multicolumn{2}{|c|}{ Model } & Sum of Squares & df & Mean Square & $\mathrm{F}$ & Sig. \\
\hline \multirow[t]{3}{*}{1} & Regression & 43.559 & 4 & 10.890 & 12.401 & $.000^{\mathrm{b}}$ \\
\hline & Residual & 56.202 & 64 & .878 & & \\
\hline & Total & 99.762 & 68 & & & \\
\hline
\end{tabular}

Sumber : Data Diolah (2020)

$\mathrm{F}_{\text {tabel }}$ bernilai 2,51 (69-4=65), $\mathrm{F}_{\text {hitung }}>\mathrm{F}_{\text {tabel, }}, 12,401>2,51$ dan sig $0,000<0,05$ maka $\mathrm{H}_{0}$ ditolak dan $\mathrm{H}_{\mathrm{a}}$ diterima yang berarti CR, QR, NPM dan ROE mempengaruhi Harga Saham pada perusahaan sektor food and beverages yang tercatat di BEI tahun 2015-2019. 


\section{Pengujian Hipotesis Secara Parsial (Uji Statistik t)}

Uji t digunakan untuk menguji apakah variabel independennya berpengaruh terhadap variabel dependen. Hal tersebut dibuktikan dengan hasil pengolahan datanya yaitu :

Tabel 10. Hasil Uji Statistik t

\begin{tabular}{|c|c|c|c|c|c|c|}
\hline \multicolumn{7}{|c|}{ Coefficients $^{\mathrm{a}}$} \\
\hline \multirow{2}{*}{\multicolumn{2}{|c|}{ Model }} & \multicolumn{2}{|c|}{ Unstandardized Coefficients } & \multirow{2}{*}{$\frac{\text { Standardized Coefficients }}{\text { Beta }}$} & \multirow{3}{*}{$\frac{\mathrm{t}}{24.282}$} & \multirow{3}{*}{$\frac{\text { Sig. }}{000}$} \\
\hline & & B & Std. Error & & & \\
\hline \multirow[t]{5}{*}{1} & (Constant) & 10.587 & .436 & & & \\
\hline & Ln_CR & -.578 & .447 & -.246 & -1.294 & 200 \\
\hline & Ln_QR & .344 & .339 & .182 & 1.016 & .313 \\
\hline & Ln_NPM & 1.058 & 268 & .763 & 3.941 & .000 \\
\hline & Ln_ROE & -.236 & .282 & -.170 & -.837 & .406 \\
\hline
\end{tabular}

Sumber : Data Diolah (2020)

Hasil pengujiannya secara individual yaitu :

1. Nilai tabel Current Ratio sebesar $1,997(69-4=65)$, nilai $t_{\text {hitung }}(-1,294)>$ nilai $t_{\text {tabel }}(-$ $1,997)$ dan nilai signifikansinya $(0,200)>0,05$ berarti CR tidak mempengaruhi harga saham di perusahaan sektor food and beverages.

2. Nilai tabel Quick Ratio sebesar 1,997 (69-4=65), nilai thitung $(1,016)<$ nilai tabel $(1,997)$ dan nilai signifikansinya $(0,313)>0,05$ berarti QR tidak mempengaruhi harga saham di perusahaan sektor food and beverages.

3. Nilai tabel Net Profit Margin sebesar 1,997 (69-4=65), nilai thitung $(3,941)>$ nilai tabel $(1,997)$ dan nilai signifikansinya $(0,000)<0,05$ berarti NPM mempengaruhi harga saham di perusahaan sektor food and beverages.

4. Nilai tabel Return on Equity sebesar 1,997 (69-4=65), nilai thitung $(-0,837)<$ nilai $t_{\text {tabel }}$ $(1,997)$ dan nilai signifikansinya $(0,406)>0,05$ berarti ROE tidak mempengaruhi harga saham di perusahaan sektor food and beverages.

\section{Pengaruh Current Ratio Terhadap Harga Saham}

\section{PEMBAHASAN}

Hasil penelitian ialah CR berpengaruh negatif dan tidak signifikan pada harga saham pada perusahaan sektor food and beverages yang tercatat di BEI tahun 2013-2019. Hasil ini sejalan dengan penelitian oleh (Sukayasih et al., 2019) yang menunjukkan bahwa Current Ratio berpengaruh negatif terhadap harga saham dan hasil ini tidak sejalan dengan penelitian oleh (Kundiman \& Hakim, 2017) menunjukkan bahwa Current Ratio berpengaruh dan signifikan terhadap harga saham. Current Ratio seharusnya menjadi salah satu acuan investor dalam berinvestasi. Current Ratio pada dasarnya menggambarkan kemampuan perusahaan dalam memenuhi kewajiban lancarnya dengan menggunakan aktiva lancar. Namun, pada kondisi perusahaan yang ada, investor cenderung tidak menggunakan CR dalam pelaksanaan investasinya. Investor cenderung melihat aspek lain, seperti analisis fundamental lainnya, pergerakan big money, dan tren pasar. Hal ini menjadikan Current Ratio menjadi tidak berpengaruh pada kenaikan harga saham. 
Owner: Riset \& Jurnal Akuntansi

e-ISSN : 2548-9224 |p-ISSN : 2548-7507

Volume 5 Nomor 5, Agustus 2021

DOI : https://doi.org/10.33395/owner.v5i2.481

\section{Pengaruh Quick Ratio Terhadap Harga Saham}

Hasil penelitian menggambarkan QR berpengaruh positif dan tidak signifkan pada harga saham pada perusahaan sektor food and beverages yang tercatat di BEI Periode 20132019. Hasil penelitian ini sejalan dengan penelitian sebelumnya yang dilakukan oleh (Sari, 2020) menunjukkan bahwa Quick Ratio berpengaruh positif terhadap harga saham dan tidak sejalan dengan penelitian yang dilakukan oleh (Suryanengsih \& Kharisma, 2020) yang menunjukkan bahwa Quick Ratio tidak berpengaruh terhadap harga saham. Quick Ratio seharusnya menjadi acuan bagi investor dalam berinvestasi. Tetapi, kondisi pada perusahaan yang peneliti amati berbeda. Investor yang melihat nilai aktiva lancar yang tinggi, menggambarkan dana atau aktiva perusahaan menganggur. Hal tersebut tentu mencerminkan kondisi perusahaan yang kurang baik dalam pemanfaatan aktiva lancar. Semakin tinggi nilai persediaan, juga menunjukkan kemampuan perusahaan yang kurang optimal dalam penjualan. Aktiva lancar dan persediaan merupakan indikator dalam Quick Ratio. Hal ini menjadikan Quick Ratio tidak berpengaruh signifikan terhadap harga saham.

\section{Pengaruh Net Profit Margin Terhadap Harga Saham}

Hasil penelitian menunjukkan bahwa NPM mempengaruhi dengan positif dan signifikan pada harga saham di perusahaan sektor food and beverages yang tercatat di BEI periode 2013-2019. Hasil penelitian ini sejalan penelitian oleh (Amalya, 2018) yang menunjukkan bahwa Net Profit Margin berpengaruh positif terhadap harga saham dan tidak sejalan dengan penelitian yang dilakukan oleh (Ambarwati et al., 2019) menunjukkan bahwa Net Profit Margin berpengaruh negatif terhadap harga saham. Dalam analisis Net Profit Margin, mencakup penjualan bersih dan laba bersih. Net Profit Margin menjadi salah satu dasar bagi investor dalam menentukan emiten yang akan diinvestasikan. Investor melihat pertumbuhan laba bersih dan penjualan bersih yang baik menunjukkan kinerja perusahaan yang optimal dan layak untuk diinvestasikan.

\section{Pengaruh Return on Equity (ROE) Terhadap Harga Saham}

Hasil penelitian memperlihatkan jika ROE berpengaruh negatif dan tidak signifikan pada harga saham pada perusahaan sektor food and beverages yang tercatat di BEI tahun 2013-2019. Hasil penelitian ini sejalan dengan penelitian yang dilakukan oleh (Alipudin, 2016) menunjukkan bahwa Return on Equity berpengaruh negatif terhadap harga saham dan tidak sejalan dengan penelitian yang dilakukan oleh (Ramdayanti et al., 2019) yang menunjukkan Return on Equity berpengaruh positif dan signifikan terhadap harga saham dan Return on Equity menghitung perbandingan laba bersih dengan total aktiva. Return on Equity menjadi salah satu poin bagi para investor dalam menanamkan modalnya. Namun, kondisi tersebut berbeda pada data yang peneliti amati. Investor cenderung memperhatikan analisis yang lain, seperti tren pasar, in-out flow, dan lain - lain dibanding analisis Return on Equity.

\section{KESIMPULAN}

Penelitian ini dilakukan untuk melihat pengaruh Current Ratio, Quick Ratio, Net Profit Margin, dan Return on Equity terhadap harga saham pada perusahaan sektor food and beverages yang terdaftar di Bursa Efek Indonesia tahun 2013 - 2019. Dari hasil penelitian 
yang dilakukan, maka ditarik kesimpulan, yakni secara parsial Current Ratio berpengaruh negatif dan tidak signifikan terhadap harga saham. Quick Ratio secara parsial berpengaruh positif dan tidak signifikan terhadap harga saham. Net Profit Margin secara parsial berpengaruh positif dan signifikan terhadap harga saham. Return on Equity secara parsial berpengaruh negatif dan tidak signifikan terhadap harga saham. Secara simultan, Current Ratio, Quick Ratio, Net Profit Margin, dan Return on Equity berpengaruh dan signifikan terhadap harga saham. Peneliti menyadari ada keterbatasan dalam penelitian ini, yaitu penelitian ini hanya berfokus pada perusahaan sektor food and beverages, variabel penelitian yang hanya berfokus pada rasio likuiditas dan rasio profitabilitas, dan keterbatasan lainnya. Saran bagi peneliti - peneliti selanjutnya adalah peneliti selanjutnya dapat melakukan penelitian dengan topik yang sama dengan variabel berbeda, sektor perusahaan yang lain, dan tahun penelitian yang terkini. Saran bagi perusahaan sektor food and beverages yang dapat peneliti berikan adalah perusahaan diharapkan memperhatikan kinerja perusahaan terutama Net Profit Margin, dikarenakan Net Profit Margin berpengaruh dan signifikan terhadap kenaikan harga saham.

\section{REFERENSI}

Afiah Aprilia Abbas, D. (2019). Pengaruh Return On Assets (ROA), Return on Equity (ROE) Dan Earning Per Stock (EPS) Terhadap Harga Saham Pada Perusahaan Makanan Dan Minuman Yang Terdaftar Di Bursa Efek Indonesia (BEI). Journal System: Open Sciense Framework, null(23), 301-316.

Alfiah, N., \& Diyani, L. A. (2018). Pengaruh Roe Dan Der Terhadap Harga Saham Pada Sektor Perdagangan Eceran. Jurnal Bisnis Terapan, 1(02), 47-54. https://doi.org/10.24123/jbt.v1i02.794

Alipudin, A. (2016). Pengaruh Eps, Roe, Roa Dan Der Terhadap Harga Saham Pada Perusahaan Sub Sektor Semen Yang Terdaftar Di Bei. JIAFE (Jurnal Ilmiah Akuntansi Fakultas Ekonomi), 2(1), 1-22. https://doi.org/10.34204/jiafe.v2i1.521

Amalya, N. T. (2018). Pengaruh Return on Asset, Return on Equity, Net Profit Margin Dan Debt To Equity Ratio Terhadap Harga Saham. Jurnal SEKURITAS (Saham, Ekonomi, Keuangan Dan Investasi), 1(3), 157-181. https://doi.org/10.32493/skt.v1i3.1096

Ambarwati, P., Enas, E., \& Lestari, M. N. (2019). Pengaruh Net Profit Margin (NPM) dan Return on Equity (ROE) Terhadap Harga Saham (Studi Kasus Pada PT. Bank Central Asia Tbk, Yang Terdaftar Di Bursa Efek Indonesia Periode 2007-2017) ". Business Management and Extrepreneurship Journal, 1(2), 100-119.

Fahmi, I. (2017). Analisis Laporan Keuangan. Bandung: Alfabeta.

Fitrianingsih, D., \& Budiansyah, Y. (2019). Pengaruh Current Rasio Dan Debt To Equity Ratio Terhadap Harga Saham Di Perusahaan Food and Beverage Yang Terdaftar Di Bursa Efek Indonesia Periode 2013 - 2017. Jurnal Riset Akuntansi Terpadu, 12(1), 144-167. https://doi.org/10.35448/jrat.v12i1.5347 
Kasmir, K. (2018). Analisis Laporan Keuangan. Jakarta: PT. Raja Grafindo Persada.

Kundiman, A., \& Hakim, L. (2017). Pengaruh Current Ratio, Debt To Equity Ratio, Return on Asset, Return on Equity Terhadap Harga Saham Pada Indeks Lq 45 Di Bei Periode 2010-2014. Among Makarti, 9(2), 80-98. https://doi.org/10.52353/ama.v9i2.140

Mangeta, S. A., Mangantar, M., Baramuli, D. N., Manajemen, J., Sam, U., \& Manado, R. (2019). Analisis Return on Equity (Roe), Net Profit Margin (Npm), Dan Return on Asset (Roa) Terhadap Harga Saham Properti Di Bei (Periode 2013-2017). Jurnal EMBA: Jurnal Riset Ekonomi, Manajemen, Bisnis Dan Akuntansi, 7(3), 3768-3777. https://doi.org/10.35794/emba.v7i3.24876

Nahariyah, R. (2017). Pengaruh Current Ratio (Cr), Debt To Equity Ratio (Der), Return on Asset (Roa), Return on Equity (Roe), Dan Earning Per Share (Eps) Terhadap Harga Saham Pada Perusahaan Sub Sektor Konstruksi Bangunan Yang Terdaftar Di Bursa Efek Indonesia Periode 2011-201. Jurnal Ilmu Administrasi Bisnis, 6(4), 310-324.

Ramdayanti, R., Soepardi, E. M., \& Herdiyana, H. (2019). Pengaruh Quick Ratio (Qr), Total Assets Turnover (Tato), Return on Equity (Roe), Earning Per Share (Eps) Dan Inflasi Terhadap Harga Saham Pada Perusahaan Sub Sektor Farmasi Yang Terdaftar Di Bursa Efek Indonesia Tahun 2013-2017. Jurnal Online Mahasiswa (JOM) Bidang Manajemen, 4(4).

Sari, D. I. (2020). PENGARUH QUICK RATIO TOTAL ASSET TURNOVER DAN RETURN on INVESTMENT TERHADAP HARGA SAHAM. Balance: Jurnal Akuntansi Dan Bisnis, 5(2), 123. https://doi.org/10.32502/jab.v5i2.2876

Sari, W. P. (2018). Pengaruh Rasio Keuangan terhadap Harga Saham pada Perusahaan Manufaktur Go Public yang Terdaftar di Bursa Efek Indonesia. Jurnal Ilmiah Syaklandsea, 2(1), 43-52.

Sukayasih, A., Mahfudnurnajamuddin, \& Ramlawati. (2019). Pengaruh Current Ratio, Return On Asset, dan Debt To Equity Ratio terhadap Harga Saham Perusahaan yang Terdaftar di BEI Sektor Properti dan Real Estate. PARADOKS: Jurnal Ilmu Ekonomi, $2(3), 81-88$.

Suryanengsih, T. D., \& Kharisma, F. (2020). Pengaruh Current Ratio dan Quick Ratio Terhadap Harga Saham pada Perusahaan Consumer Goods yang Tercatat di BEI Periode Tahun 2013-2017. Borneo Student Research, 1(3), 1564-1570.

Tewal, B., \& Jan, A. B. H. (2017). Pengaruh Current Ratio, Der, Roa Dan Npm Terhadap Harga Saham Pada Perusahaan Food and Beverages Yang Terdaftar Di Bei (Periode 2013-2015). Jurnal Riset Ekonomi, Manajemen, Bisnis Dan Akuntansi, 5(2), 18131822. https://doi.org/10.35794/emba.v5i2.16399 